\title{
Vertical Partial Laryngectomy
}

\section{施行後の喉頭像}

*浅 野 尚

\section{1. 序言}

Partial Laryngectomy の機能的予後を決定 する因子として術後喉頭の形態的変化が重要な 役割を演じている。その形態の変化には切除範 囲が大きく関与することは当然であるが，各症 例間にお污る最大公約数的な共通所見の有無及 びその差を追求することは, 術後の機能を論ず る場合に非常に重要な問題である。即ちこれら の手術が，大多数の場合悪性腫愊を対称として 施行される以上, 術式の選定は, 当然治癒率の 向上を第一義の目的として決定されるべきこと は云うまでもないが，その範囲内での Modification が許されるとすれば，そこに生体が本来 持つている Potential の保存乃至その助長と云 う点も考慮されるべきであると思う。前回の本 学会における喉頭部分切除術のシンポジウムの 中で, 金子は Vertical Partial Laryngectomy の適応の基準は, 悪性度の低いものであれば従 来の諸家のそれより拡げてよく，一側の声帯癌 で声門下腔進展が数 $\mathrm{mm}$ 以内のもの, 及び前連 合に達していてもよいが反対側声帯に進展して いないもの，更に，患側喉頭室，仮声帯進展の あるもの, 又びリンパ節を触知するものも適応 の範囲にあると述べている。この適応 は anatomical に決定されたものであるが，このよう な適応の下に施行された術後の喉頭像を検討す ることは, ひるがえつてもら一度, 適応の基準 決定に functional な立場から見て大きな意義 を持つものと考える。その意味で今回我々は Vertical Partial Laryngectomy.を施行した患者 の術後の喉頭像を中心に考察を試み 2,3 の知見

* 千葉大学医学部耳鼻咽喉科教室 大学院学生 （主任 北村 武教授）
を得たのでここに報告する。

\section{2. 検査対称並びに方法}

検査対称は当科で Vertical Partial Laryngectomy を施行した患者 17 名のうち術後の諸検查 を施行し得た例15名についてである。手術々式 は, Hemilaryngectomy（即ち Gluck-Soerensen 及び Hautant 氏術式）並びに北村式 Frontolateral Laryngectomy である。これらの術式 について簡単にその切除範囲を述べるならば Gluck-Soerensen による手術では甲状軟骨及び 輪状軟骨の患側半分を切除し，披裂軟骨も，患 側を全剔する。Hautant 氏術式では甲状軟骨は 患側の外側縁を少々残すが，正中線より少し健 側を含めて切除し，輪状軟骨は患側ほぼ前半を 切除，披裂軟骨も患側を全剔する。北村式では 甲状軟骨は患側前 $1 / 3$ を切除するが輪状軟骨は残 し，披裂軟骨は一部又は全部切除する。患側に 鼻中隔粘膜を植えることもある。要するに最も 典型的な Hemilaryngectomy が Gluck-Soerensen であり北村式は conservative, Hautant のは その中間と云うことになる。

検查方法怕 $\mathrm{X}$ 線断層撮影, Contrast Laryngography, Laryngocamera 等であり，X線断層撮 影は甲状軟骨結節先端より $1.5 \mathrm{~cm}$ 後方を第一層 とし，以下 $5 \mathrm{~mm}$ ごとに合計四層撮影し，第二 層又は第三層を観察の対称とした。観点を次の 二点に置いた。即ち，1）非術側仮声帯の腫大の 程度，2）非術側喉頭の術側に向から腫大偏位 である。判定規準として仮声帯の腫大の程度を 次の四段階に分けた。即ちX線像では，非術側 声帯遊離縁を通る垂線を仮定し,

(H)……仮声帯がその垂線を越えて術側に腫 大しているもの 
(H)……声帯と同一垂線上にあるもの

$(+) \cdots \cdots$ 正常の仮声帯と比べて腫大している と思われるもの

(一)…正常と変わりないもの

とし, 喉頭像では,

(HI) ……非術側声帯が明視し得ない程仮声帯 が腫大しているもの

$(+1) \cdots \cdots$ 小ずかに声帯遊離縁が認められるも の

$(+) \cdots \cdots$ 正常の仮声帯に比べて腫大している と思われるもの

$($ - $) \cdots \cdots$ 正常と変わりないもの

とした。以下順次各症例について検討するわけ であるが，総体的に云えること殆んど全例に 仮声帯の腫大が認められたことである。又，そ の時期は，術後 1ケ月を経た症例で既にこのよ らな所見が成立しているのを確認し得たのであ る。

以下各術式別に代表的な例の $\mathrm{X}$ 線像, 喉頭像 についての検討を加える。

第 1 例 49才 (手術時) 男性（図 1

4)

術式 Gluck-Soerensen

観察時期 術後13个月

所見 X線断層撮影及び Contrast Laryngo- graphy で術側は気管内壁面とほぼ同一線上 をなし内腔に向かう膨隆治んど認められな い。健側は声帯特に仮声帯が正中を越えて腫 大している。Laryngocameraで呼吸停止時に も発声時にも声帯を被いかくす程術側仮声帯 が腫大している。喉頭前後径の短縮も見られ る。

第 3 例

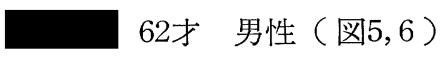

術式 Hautant Type +術側に鼻中隔粘膜を 移植

観察時期 術後11ケ月

所見 X線像で健側仮声帯が声帯遊離縁まで 達している。Laryngocamera でも同様 の所見である。喉頭前後径も短縮してい る。

第5例—55才 男性（図 7)

術式 北村式 Frontolateral Laryngectomy （植皮なし）

観察時期 術後 6 ケ月

所見 X線像及び Laryngocamera で仮声帯 の腫大は声帯遊離縁まで及んでいる。喉 頭前後径の著しい短縮が特徵的である。

第15例—57才 男性（図 8)

術式 北村式Frontolateral Laryngectomy + 術側に鼻中隔粘膜を移植

表 1

\begin{tabular}{|c|c|c|c|c|c|c|c|c|c|}
\hline \multirow{2}{*}{ 患 者 } & \multirow{2}{*}{ 術 側 } & \multirow{2}{*}{ 術 式 } & \multirow{2}{*}{ 植 皮 } & \multirow{2}{*}{ 披裂軟骨 } & \multirow{2}{*}{$\begin{array}{l}\text { X線撮影 } \\
\text { 迄の日時 }\end{array}$} & \multicolumn{2}{|c|}{ 反対側仮声帯の肥大 } & \multirow{2}{*}{$\begin{array}{l}\text { 前後径 } \\
\text { 短縮 }\end{array}$} & \multirow{2}{*}{ 声帯振動 } \\
\hline & & & & & & $\mathrm{X}$ 線 & $\begin{array}{l}\text { ラリンゴ } \\
\text { カメラ }\end{array}$ & & \\
\hline & $\mathrm{L}$ & G.S. & - & 切 & $13 \mathrm{M}$ & $+\sim H$ & H & 短 & $H$ \\
\hline & $\mathrm{L}$ & G.S. & - & 切 & 4 & HH & & & \\
\hline & $\mathrm{R}$ & $\mathrm{HT}$ & + & 切 & 11 & $H$ & H & 短 & + \\
\hline & $\mathrm{R}$ & F L & - & 切 & 7 & H & H & & + \\
\hline & $\mathrm{R}$ & F L & - & 切 & 6 & H & H & 短 & \\
\hline & L & F L & + & 切 & 1 & H & HH & 短 & \\
\hline & L & F L & + & 切 & 3 & $H$ & & & \\
\hline & $\mathrm{R}$ & F L & + & 切 & 12 & $H$ & + & 短 & + \\
\hline & $\mathrm{R}$ & F L & - & 残 & & & & & + \\
\hline & $\mathrm{R}$ & F L & - & 残 & 1 & H & H & 短 & \pm \\
\hline & $\mathrm{R}$ & F L & + & 残 & 2 & H & Ht & 短 & \\
\hline & L & F L & + & 残 & 1 & $H$ & + & 短 & \\
\hline & L & F L & + & 残 & 7 & H & $H$ & 短 & + \\
\hline & $\mathrm{R}$ & F L & + & 残 & & + & - & & $H$ \\
\hline & $\mathrm{R}$ & F L & + & 残 & 15 & $H$ & + & 短 & + \\
\hline
\end{tabular}




\section{観察時期 術後15 万月}

所見 X線像で仮声帯はやや腫大している。 Laryngocameraで仮声帯の下に声帯遊離 縁がわずかに見える。喉頭前後径は短縮 している。

以上の如き検査を15名に就いて行なつた結果 は第 1 表に示す如くである。即ち 1 例を除いて 他の全例にかなり著明な仮声帯の腫大が認めら れたわけであるが，その程度を見ると夫々に少 しづつ差があるよらである。傾向として第 1 例 のように完全なHemilaryngectomyを行なつた 例に江仮声帯の著明な腫大と残存喉頭の偏位が 見られ，それにくらべて第15例のように Frontolateral Laryngetomyを行ない植皮をした例 には上記の如き変化が少ないのである。又一 方，第 5 例に見た如く喉頭前後径の短縮も大多 数に見られ，発声時にはそれが著明になる。

次にストロボカメラによつて腫大した仮声帯 の発声時に抢ける運動を調べると Vertical Component の動きを示していることがわかる。 この点は, Cordectomia unilateralis 施行後の 患側仮声帯について Oreskovic の見た所見と同 様である。これに対して健側声帯はストロボで は仮声帯の腫大のため明視することが出来な い。そこで我々の考案した超音波による方法 (Ultrasonoglottography. U.G.G.) で検査する と，少なくとも horizontal の動きは規則的で正 常と殆んど変わりないことがわかる（第 9 図）。

このような意味で少なくとも 1 侧喉頭を残し て発声機能を保存しょうと云うこの手術の基本 的な目的澾せられているわけである。

術後の音声としては㖽声が強いことは当然で あるが，会話は充分可能である。特に GluckSoerensen 型の Hemilaryngectomy を行なつた 第 1 例は Larynofissure を施行した患者にも増 して嗄声の少ない発声をしているのは注目す心゙ きことと考える。

\section{3. 考案}

以上の如く Vertical Partial Laryngectomy によつて 1 側喉頭を除去すると他側喉頭特に仮 声帯が腫大偏位することがわかつた。その $\mathrm{Me}$ chanism は何であろうか。Réthi は仮声帯発声
に法 m.stylopharyngeus と m.palatopharyngeus が役割を演じており，例えば 1 側の閉鎖筋麻痺 の際にその側の仮声帯が正中線に近づくが，こ のとき m.stylopharyngeus の肥大を指摘して いる。即ち, 彼はこの筋が m.aryepiglotticus と m.arytaenoideus $の$ pars obliqua に線維を 送つて拉り，Recessus piriformis を通つて披裂 軟骨の基部に附着していると云う。発声の際に Recessus piriformis の底が上がり二つの披裂軟 骨が近づき内側に傾くのはこの筋の作用である としている。一方 Oreskovic は, 仮声帯の移動 は Sphincter として行動する内筋の作用であり m.arytaenoideus と m.thyreoarytaenoideus の pars descendens をその役に任じている。 m. thyreoarytaenoideus $の$ pars descendens は甲 状軟骨の正中線より $2.2 \mathrm{~mm}$ 外側, 上縁より 0.2 $\mathrm{mm}$ 下方よりはじまり，後下方に向かい披裂軟 骨の Proc. muscularisの上に附着するが，他の 喉頭筋と異なり Morgagni 室の外側を走ると云 う。彼は又, Cordectomy を以前に行ない, そ の後再発し Total Laryngectomy を施行した例 を組織学的に検索し, m. thyreoarytaenoideus $の$ pars descendens $の$ 肥大 (両側特に Cordectomyを行なつた術側に著明なのであるが）を 認め, 仮声帯の腫大の原因をこの筋に求めた。 更に仮声帯内の弾性線維が増量するためだとも 云つている。

我々の症例, 即ち放射線療法及び喉頭截開術 後に再発し喉頭全剔を行なつた症例の健側喉頭 の組織所見でも筋の肥大と弾性線維の増殖を認 めている（図10）。又我々の症例の多くは, Laryngocamera に見るように仮声帯の腫大は その前半部に著明のようである。組織学的に仮 声帯は前部に弾性線維, 後部に腺組織があるこ とから考えて弾性線維の増殖による仮声帯の肥 大は承認せられてよいように思う。Réthi の云 う喉頭後側面から披裂軟骨に至る隆起を我々の 症例では 1 例も見出し得なかつたのであり,こ の点に抒いて Rethi の説は納得のゆかぬもので ありむしろ Oreskovic の説に同意出来そらで あるが, 更に明確な成因については今後の研究 に待たなければならない。 
気食会報一 18 巻

\section{4. 結語}

我々は当科で施行した Vertical Partial Laryngectomy 後の残存喉頭の形態学的検索を行 なつた。共通所見として，健側仮声帯の術側へ の腫大偏位が見られ，術側に移植をしない例の 方が移植した例に比べて腫大が著明のように見 えた。又少なくとも 1 ケ月以内でこのような変 化が形成されていることがわかつた。その原因 として, 我々は仮声帯内の弾性線維の肥大と, m.thyreoarytaenoideus $の$ Pars descendens $の$ 肥大を考えたいのであるが，この点に関して不 明な点が多く今後の研究に待つ次第である。

稿を終るに当り, 御指導御校閲を賜わった恩師北 村武教授に染甚なる感謝の意を表する。又，終始御
指導御助言下さった金子敏郎講師に深謝いたしま す。

本論文の要旨は第18回日本気管食道科学会で発表 した。

\section{参考文献}

1）金子敏郎：気食会報 16巻，6号. 1965 .

2) J. Leroux-Robet : Ann. Oto-Laryng. (Paris) 74, 1 2, 1957.

3) M. Oreskovic : Rev. de Laryngologie $80,5 \sim 6$, 1959.

4) M. Oreskovic: Pev. de Laryng. 82,11 12, 1961

5) Denker Kahler : Handbuch d.Hals-Nasen-Ohren Heilkunde I, 1925.

6) J. Berendes, R. Link, F.Zöllner : H. N. O.Heil kunde I. 1963

7) J. Falbe-Hansen et al : The Journal of Laryngology and Otology. 78, Jan. 1964

\section{投稿 規 定}

1）投稿者は本学会々員であること。

2）原稿汢新かなづかいで, 楷書, 横書, 簡潔明膫なること。句読点を正確に, 外国語, 薬品名はカタカ ナを用い「」や—をつけないこと。

3）論文は組上り 3 頁まで（400字詰原稿用紙約15枚），但し特例を認めることがあります。規定頁数を超 える場合は超過分の実費並びに超過郵送料をいただきます。

4） 200 字以内の和文抄録（その英訳も一緒に）を必ずつけて下さい。但し英訳のない場合は英文抄録作 製料をいただきます。

5）文献重要なもののみにして著者名，題名，雑誌名，巻，頁，年号の順に統一して下さい。

6）附図汢白紙に墨ではつきり描いて下さい。色で描いたもの，又注不鮮明なものは製版ができず描き直 すことになりますが，その場合は実費をいただきます。図版，写真版の製版は実費をいただきます。

7）別雨御希望の方沬論文と同時に御申込み下さい。但し実費をいただきます。

8）原稿㳉東京都新宿区信濃町 35 慶応大学医学部内 日本気管食道科学会宛お送り下さい。揭載の採否は 編集員におまかせ下さい。 
気食会報一 18 巻

図 1

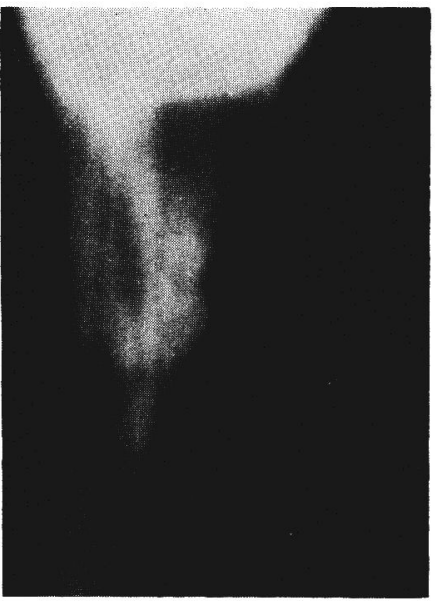

図 3（呼吸停止時）

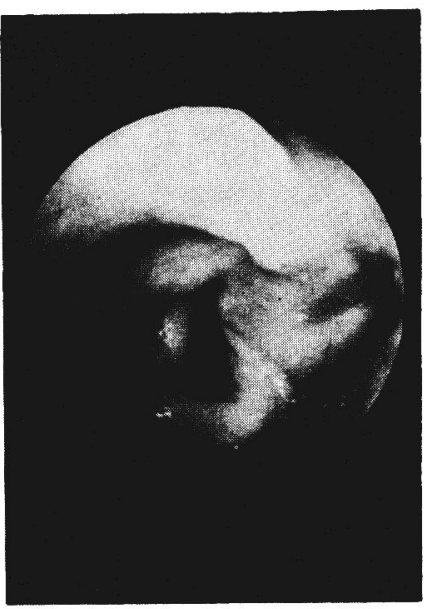

図 4（発声時）

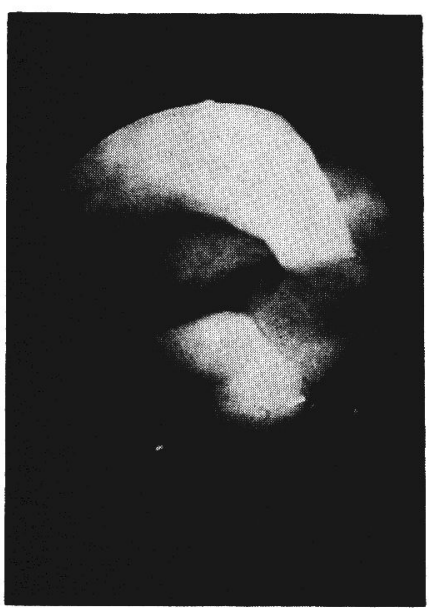

図 2

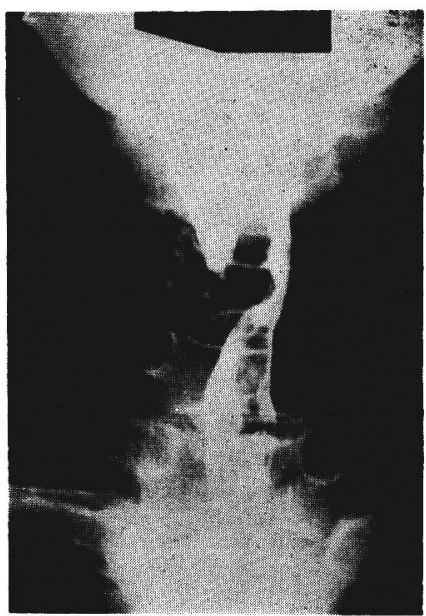

図 $3^{\prime}$
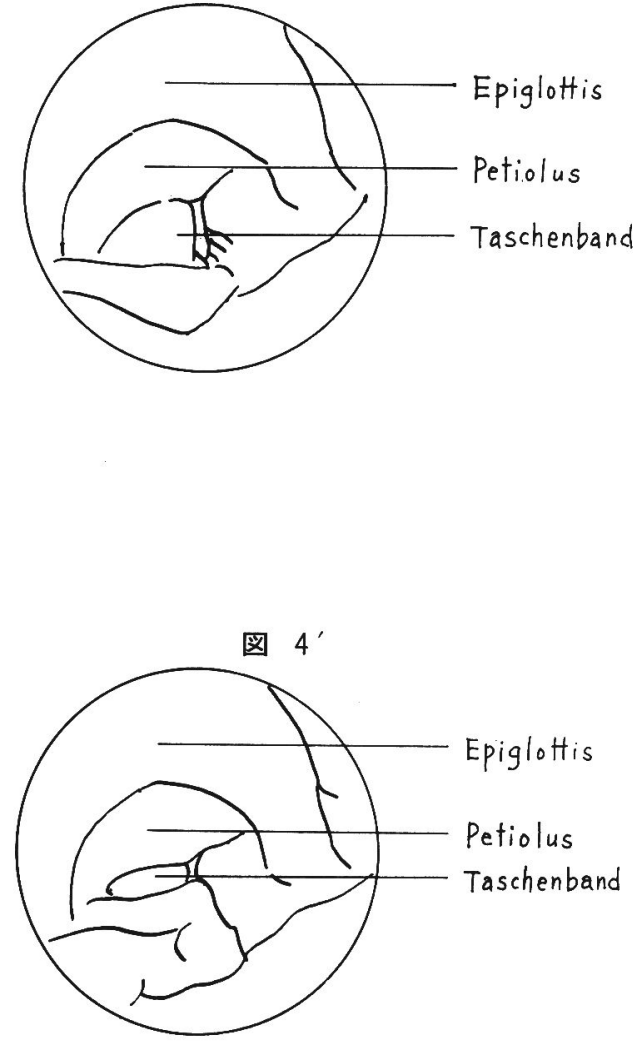
気食会報 -18 巻

図 5

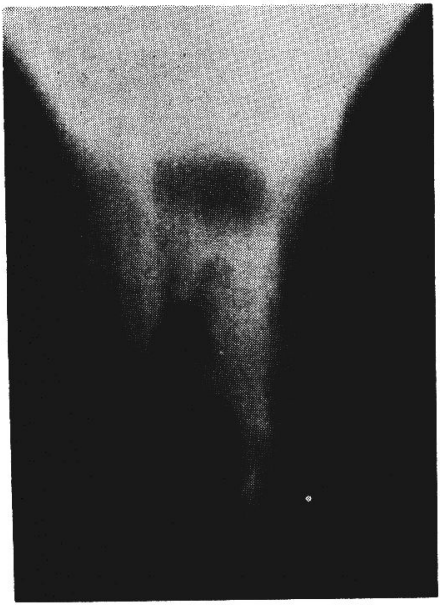

図 6

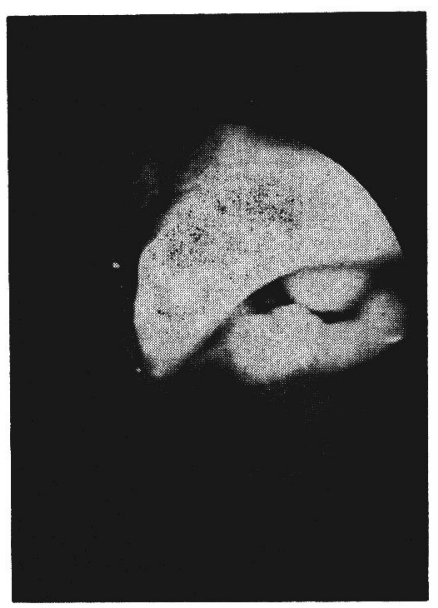

図 7

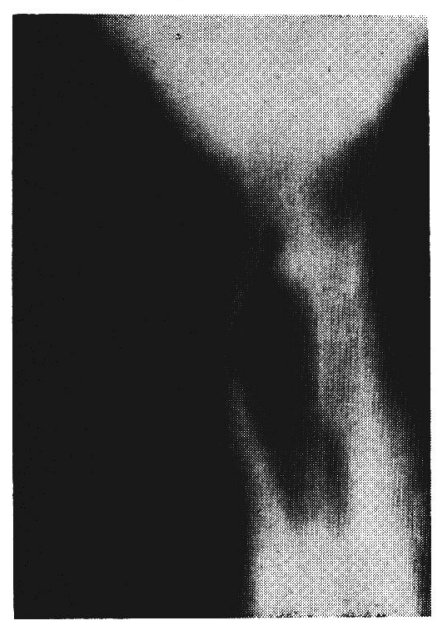

図 5'

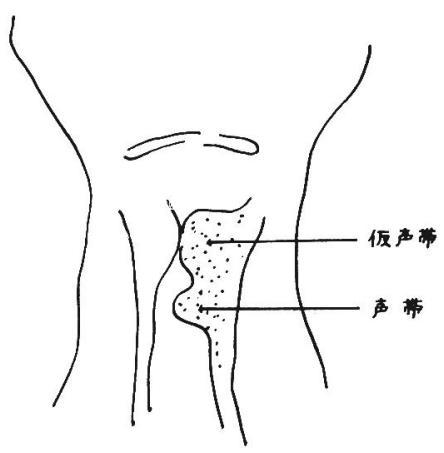

図 $6^{\prime}$

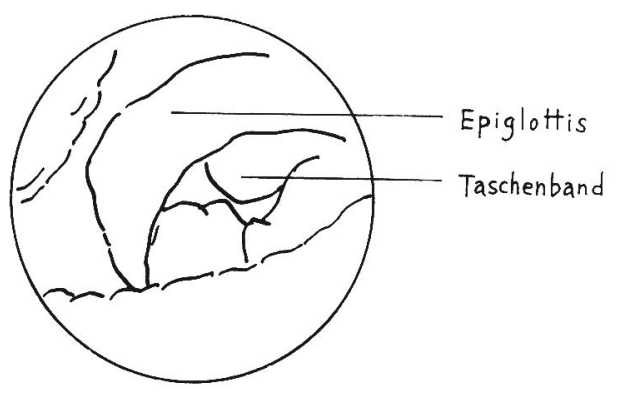

図 $7^{\prime}$

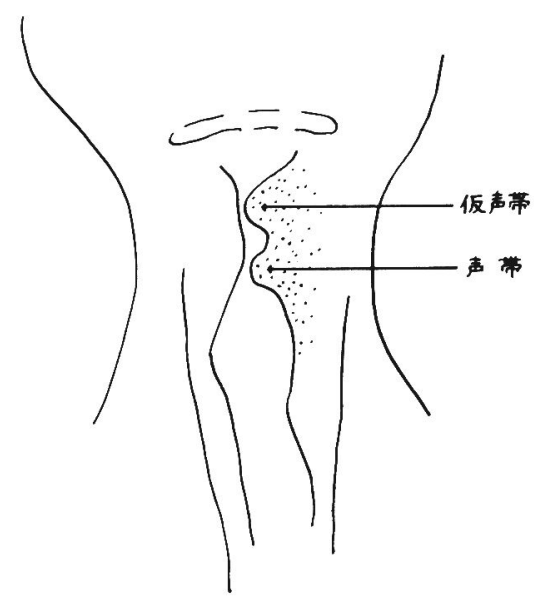


気食会報一 18 巻

図 8
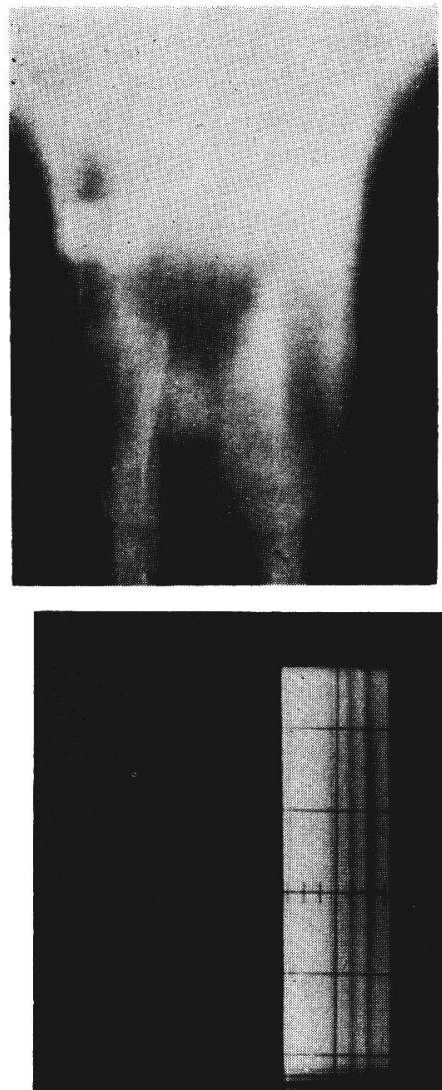

(a)

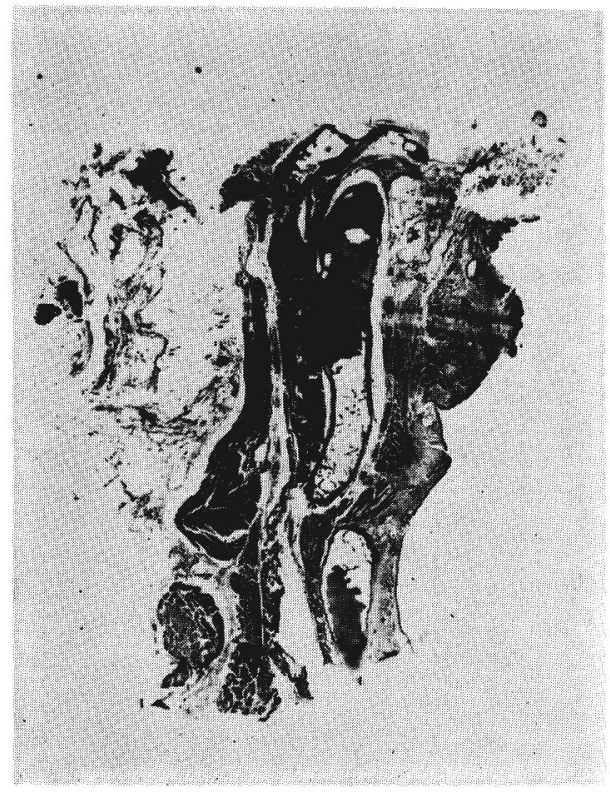

図 10

$\leftarrow$ 仮声帯

$\leftarrow$ 声 帯
図 $8^{\prime}$

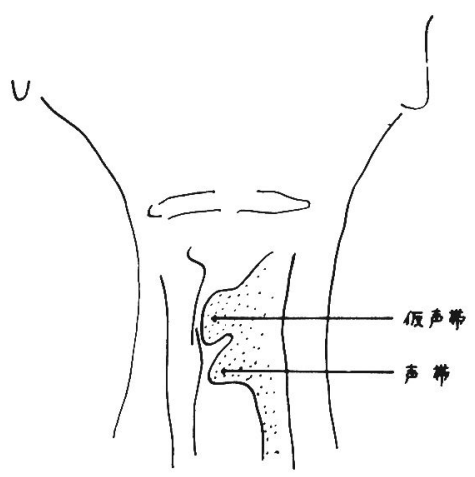

図 9

(a) 送信パルス

(b) 声帯振動曲線 